\title{
On the Formation of Personal Space and Self-Boundary Structures in Early Human Development: The Case of Infant Stranger Reactivity
}

\author{
Thomas M. HoRner \\ University of Michigan Medical School
}

\begin{abstract}
Personal space and self-boundary are, respectively, sociological and intrapsychological concepts that refer to a complex of behavioral and subjective events between and within individuals. While there are large bodies of literature concerned with each of these concepts, literature that cuts across many disciplines of study, there has never been an integration of these concepts around specific human developmental issues. The present article focuses upon human infancy as a period in which both personal space and self-boundary phenomena can be observed. Developmental links between personal space and self-boundary phenomena in infancy and adulthood are outlined and discussed.
\end{abstract}

The importance of spatial and territorial factors in human social behavior has been well established by numerous observational and experimental studies in ethology, anthropology, sociology, and psychology. Personal space, one central component of spatial and territorial factors in general, has been studied frequently. A number of reviews of the literature concerned with personal space, as well as the high number of studies of the phenomenon that are cited in Psychological Abstracts, indicate the value of the concept to behavior scientists (see, for example, Baldassare, 1978; Edney, 1974; Evans \& Howard, 1973; Hayduck, 1978; Pederson \& Shears, 1973; Sundstrom \& Altman, 1976). These reviews have variously focused on its normative aspects within and between cultures, its relation to various demographic variables, its basis in communication and social interaction, and its methodological and theoretical problems. Beyond these reviews, well-known treatments of the topic of personal space are works by Argyle (1975), Ashcraft and Sheflen (1976), Goffman (1971), Hall (1966), Sommer (1959, 1969), and Watson (1970).

With few exceptions, authorities have regarded the concept of personal space as a quasi-discrete and circumscribable entity that regulates to some extent the individual's transactions with others. As such it is an integral component of the individual's representation of self and sense of subjectivity (see, for example, Goffman, 1963; 1971; Lewin, 1936). Personal space differs from territory in that it accompanies the individual's

Reprints may be obtained from the author at the Department of Psychiatry, University of Michigan Medical School, Ann Arbor, MI 48109. 
movements. The actual size or extent of personal space varies according to various dimensions of social interaction (e.g., personal attraction) and subject-environment states (see Baldassare, 1978; Pederson \& Shears, 1973). Thus, Burgoon and Jones (1976) synthesized a definition of personal space as follows:

The invisible volume of space that surrounds an individual $[;] \ldots$ an invisible, dynamic and transportable space the site of which is governed by the individual's felt need at any point in time. (p. 131)

The function of personal space has been the subject of several theoretical speculations (see Evans \& Howard, 1973). Pertinent to the present study are Altman's (1979), Hall's (1964, 1966), Sommer's (1959), and Goffman's (1971) views that personal space functions in a regulatory and protective fashion in the individual's relations with others. Altman emphasized the importance of privacy. Hall likened personal space to a protective "bubble" surrounding the individual. Goffman linked personal space directly to the self and its social interactional vicissitudes. Sommer specified four defining characteristics of personal space: It is portable; its geographic and psychological center is the individual's body; it is demarcated from the rest of the environment by invisible boundaries; intrusion into it by others arouses discomfort, causing the individual to withdraw. To these four defining characteristics I add two more. Based on various studies of ego and body boundaries, the size of an individual's personal space fluctuates according to varying social, psychological, and organismic conditions (e.g., Blatt \& Wild, 1976; Federn, 1952; Fisher \& Cleveland, 1968; Fredericks, 1969; Freeman, 1958; Goffman, 1971; Hayduck, 1978; Mallenby, 1974; Perkins-Karniski, 1978: Sanders, 1978; Schilder, 1934; Weinstein, 1969; Weiss, 1960), and they are semipermeable according to the degree of intimacy existing between the interactants. Finally, personal space behavior is a key element of communication about the self.

The psychological counterpart of personal space behavior is the selfboundary structure within the system of mental representations of body, social roles, and other categories of the self. Formulations concerning the functional significance of self-boundaries are quite similar to those made concerning personal space, especially with respect to their protective and mobile nature. For example, Fisher and Cleveland (1968) have stated that the body-image boundary, a particular component of self-boundary system,

is a screen which [the individual] interposes between himself and outer situations and which he can carry with him at all times ... Thus the boundary may be conceptualized as playing an important role in maintaining homeostasis in the course of the individual's psychological transactions with the world. It is a projection of certain assumptions about life to an area of behavioral space which separates the individual from what is "out there." (1968, pp. 354-355). 
Reviews of boundary phenomena in general and self-boundaries in particular have been made by Blatt and Wild (1976), Landis (1970), and Fisher and Cleveland (1968) (see also Fisher, 1970). These authors trace the development of self-boundary concepts in psychoanalysis and social psychology. While none of these reviews fully covers the neurophysiological and clinical neurological material that might be brought to bear on the subject (see, for example, Mettler, 1962; Popper \& Eccles, 1977), it is clear enough from the reviews that the subject matter of self-boundaries and related behavioral phenomena cuts across several distinct disciplines of study. As such, it offers points of cross-disciplinary integration of theory that are at the foundation of this presentation. ${ }^{1}$ The concepts of personal space and self-boundary are, respectively, social-behavioral and intrapsychic counterparts of the same phenomenon.

In further considering the function of personal space, many theorists view as primary the subject's need to develop internal models of expectation regarding the other. Such expectation or contingency models allow the subject to gauge potential courses of interaction outcome (Altman, 1971; Berger \& Calabrese, 1975). According to Berger and Calabrese (1975), the interactants' " primary concern is one of uncertainty reduction or increasing predictability about the behavior of both themselves and others in the interaction" (p. 100). Goffman (1971) has charted a number of distinct categories of social organization ("preserves") existing within social encounters. These include personal space, stalls, use space, turn taking, possession territory, and information and conversational preserves. The boundaries of these preserves are signaled to others by an array of physical and symbolic markers. According to Goffman, the prototypical territorial offense is the intrusion of one individual into another's

\footnotetext{
${ }^{1}$ Basically, the reader needs to begin from the premise that the person's sense of self and its interpersonal correlate, identity, evolve within a social context that is constantly mediated by information processing structures within and under the regulation of central nervous system centers. The self, constituting an interface between the social-physical milieu and the underlying neurophysiological processes, is constructed by the converging forces of processes operating, to use Miller's (1965) general systems terminology, at levels of matter-energy and information transmission. To paraphrase a point made by Rapaport (1967 [1957]), it is through the self that the social environment exerts its control over the physiological substate, and it is by virtue of the self that physiological processes are given semiautonomy from the milieu. In the most specific and ultimate sense boundaries are defined by informational content allowing A/not A decisions to be made by information processing mechanisms of the mind. In the subjective domain one of the basic decision units is that of self/not self. Self-boundaries function at a succession of levels varying from the purely neurosensorimotor (body image) to the most abstract of mental representations. Presumably, in accordance with general principles of epigenetic development (Werner, 1940), there is in development and maturation a progression that starts with the neurobehavioral core of functioning and ends with a more broadly elaborated, highly integrated apparatus that processes information at multiple levels of abstraction.
} 
preserve without proper authorization (signaled or tacitly given). Ordinarily, individuals who are strangers to each other follow societally patterned interaction routines ("rituals," see Goffman, 1967) when encountering each other. These encounters are often regulated by the interactants' maintenance of certain degrees of anonymity (Goffman, 1971). Implied is a set of governing procedures designed either to maintain unfamiliarity or to transform the encounter by controlled degrees to one of greater familiarity. It is Goffman's special viewpoint, largely reflecting George Herbert Mead's concepts, that in encounters and relationships the focused aim of the individual is to create appearances that allow the other to see him as "unalarming" to others, as being "safely disattendable" (1971). The control of aggression and, quite significantly, the appearance of aggression is fundamental to the relational paradigms that evolve in social encounters, and they are embedded within a communication framework that is mostly nonverbal, subtle, and symbolically refined. Needs for a sense of personal effectance and affirmation of one's personal constructs may form other motivational frameworks by which to gauge interaction events (Duck, Miell, \& Gaebler, 1980).

of the many methods that have been used to study personal space phenomena in humans, most have focused on various aspects of interpersonal proximity and nonverbal interaction (e.g., gaze interaction). While self-report and projective devices have been employed for the purpose of studying the proximity variable, the most effective methods have been tional paradigms have included ongoing interactions (e.g., conversational distance) and spatial invasions (e.g., experimenter or his/her confederate moves close to an unsuspecting subject) (Sundstrom \& Altman, 1976), and various "stop-distant" techniques (Hayduck, 1978) wherein the subject stops the approaching experimenter at whatever point discomfort is aroused. Various studies have determined that the actual comfortable distance is determined by several factors, including age, gender, degree of acquaintance and friendship, personal attraction, cultural background, need for affiliation, and psychopathology. (See reviews by Evans \& Howard (1973), Hayduck (1978), Sundstrom \& Altmann (1976).)

Proximity behavior, simple as it is to describe and measure, reflects an extremely complex set of intrapsychic and social-interactional forces, most of which are hidden from direct review. Substantial individual differences in response style and personal spacing exist (Porter, Argyle, \& Salter, 1970). Hypothesis and inferences concerning the nature or proximity behavior derive chiefly from introspective-intuitive efforts on the part of observers, comparisons of the behaviors and the self-expressions of individuals in varying degrees of proximity to each other, and speculations along established theoretical models of human social behavior. Nevertheless, studies of proximity behavior remain of considerable 
heuristic value within the larger realm of social psychological theory and research, being "important opportunit(ies) to better understand the form and function of human social life" (Baldassare, 1978).

The remainder of this presentation deals with the topic of personal space in infancy, specifically the first year of life. It takes as its starting point the infant's capacity for negative reactions when confronted by strangers, a phenomenon that is typically obervable starting within the second 6 months of the first year. This presentation will show that negative stranger reactions of infancy correspond directly to processes occurring in adult social interactions with unfamiliar persons. The thesis of this essay will be that with the onset of the capacity for fearful or cautious stranger reactivity in infants there arise active (as opposed to reactive) behavioral processes that directly correspond to adulthood patterns of personal space behavior with respect to strangers. These processes are intrapsychically organized, entailing the formation of structures (ego or self-boundaries) within a developmental context where selfhood is in its earliest phases of development (see, variously, Lewis \& Brooks-Gunn, 1979; Mahler, Pine, \& Bergman, 1975).

Developmental studies of personal space phenomena over the course of childhood have not included infants. While some attention has been paid by social and developmental psychologists to evolving facets of personal space behavior, there are too few systematically derived data to suggest specific stages or steps toward personal space along the various developmental lines of social interaction. From studies of kindergarten-aged children and older, many of which are nonbehavioral (i.e., projective doll/silhouette placing techniques) and therefore less preferable than behavioral and direct observational methods (Hayduck, 1978; Mallenby, 1974), it is evident that many of the factors (e.g., ethnic membership, gender, degree of prior acquaintanceships) that influence the size and penetrability of personal space in adulthood are operative during childhood (see, for example, Aiello \& Jones, 1971; Guardo, 1969; Ihara, 1978; Loo \& Smetana, 1978; Meisels \& Guardo, 1969; Pederson, 1973; Weinstein, 1965). While some studies suggest that children's social spacing assumes adult properties by $11-12$ years of age, more concrete and systematically derived longitudinal data are needed. Interestingly, there seems to be a developmental progression in how the child is responded to when he/she invades the personal space of an adult. Younger children (age 5) tend to be reacted to by adults with facilitative behavior while older children (age 10) trend to be reacted to with avoidance or increases in motor activity, possibly anxious in nature (Dean, Willis, \& IaRocco, 1976). These findings are consistent with findings of adult studies that show that status and power factors influence personal space behavior.

By way of examining the phenomenon of infant stranger reactivity from 
the standpoint of the subject's personal space the aim of the present article is to demonstrate the former's pertinence to social-psychological study and thus to bring the topic more squarely into that domain. I shall sh $\cdot w$ that stranger reactivity in infancy follows a developmental course that may well further the social psychologist's understanding of the antecedents of personal space phenomena in adults. In order to achieve an integrative aim, I shall also briefly discuss theoretical relationships between external events and psychological events that are possible if not likely concomitants of infants' encounters with strangers. This discussion will center upon the reciprocal and obverse relationship between selfboundaries (intrapsychic) and personal space (transactional) structures. I intend to bring together empirical data and concepts from two hitherto unintegrated fields of study, aiming toward a synthesis that will enlarge the scope of observation and conceptualization about human interactions and interactive capabilities in the earliest phases of life.

\section{INFANT STRANGER REACTIVITY}

Space does not permit a comprehensive survey of literature concerning stranger reactivity in infants. Several detailed reviews of the topic obviate the necessity for one (Batter \& Davidson, 1979; Decarie, 1974; Horner, 1980; Harmon et al., 1977; Rheingold \& Eckerman, 1973; Sroufe, 1977; see also Lewis \& Rosenblum, 1974). However, some exposition of the principal findings and concepts that have emanated from the many empirical studies and theoretical treatments of the subject is required for background purposes. Much of what follows, then, is condensed from the review references just cited. The material that follows does include, however, a considerable amount of information not covered in previous reviews of infant stranger wariness and fear.

Until the 1970s, when, after Rheingold and Eckerman's (1973) critique of the infant stranger reactivity research, there began to appear studies emphasizing both the positive as well as negative emotional components of stranger reactivity (e.g., Bretherton \& Ainsworth, 1974; Corter, 1973; Eckerman \& Rheingold, 1974; Eckerman \& Whatley, 1975; Ross \& Goldman, 1977; Bretherton, Stolberg, \& Kreye, 1981), the psychological literature on stranger reactivity emphasized almost exclusively upon the anxious or fear component that appears somewhere around or shortly after the midpoint of the first year of life. Most theorists now assert that the period of development in which fear reactions to strangers arises is also a period in which positive affects and behaviors toward strangers continue to occur, even as they did in the period prior to the onset of fear reactivity. What is essentially different between the two developmental pcriods is not that stranger fear reactivity replaces positive responses as the principal affective reaction (the classical view) but that fear emerges 
as an affect capacity that expands the repertoire of behavioral and affective expressions on the part of the infant (the new idea) (see Horner, 1980). Thus, stranger fearfulness takes its place coexistent with positive reactive capacities.

\section{Developmental Course: Infancy and Beyond}

Studies of conditional responding in infancy have documented that from the second month onward there exist stable and progressively synthesized capacities for discriminative perception and differential responding on the part of the infant (Brackbill \& Koltsova, 1967; Kasatkin, 1968; Kessen, Haith, \& Salapatek, 1970; Reese \& Lipsitt, 1970, Chaps. $3-5$ ). In its earliest days, long before its reactions to the stranger involve negative affect, the human infant is capable of making perceptual discriminations between mother and nonmother in several modalities including olfaction, audition, and vision (Carpenter, 1975; MacFarlane, 1975; Roe, 1978; Turnure, 1971; Wolff, 1963). Differential responding to strangers is typically evident by about 3 months (Bayley, 1969; see also Ambrose, 1963; Barrera \& Maurer, 1981a, 1981b; Dixon, Yogman, Tronick, Adamson, Als, \& Brazelton, 1981; Fitzgerald, 1968; Thompson $\&$ Grusec, 1970.) In general, while young infants of 2 to 5 or 6 months can hardly be called sociable per se toward strangers, there is nevertheless a tractability with regard to the stranger's presence and a positively toned response proclivity that exists in most infants in this age range. At about midyear, though, there arise what seem to be transitional phenomena, including states of serious alertness and attention toward the stranger (Brody \& Axelrad, 1970, have called this "customs inspection") as well as expressions of low-level discomfort (Escalona, 1968).

The temporal onset and duration of stranger wariness and cautiousness are not difficult to sketch in broad terms. However, in accordance with all the variables that could be reasonably hypothesized to influence it, including those of temperament, the quality and quantity of the infant's prior exposures to and experiences with strangers, and the infant's qualitative relationship with the mother (one of the primary functions of which is to facilitate the infant's regulation of affectivity in general), the temporal course varies from infant to infant. Besides age, empirical studies have found a number of factors to be associated with whether or not and how much an infant reacts negatively to the appearance or approach of a stranger. They include the gender of the stranger (Brooks-Gunn \& Lewis; Greenberg et al., 1973; Morgan \& Ricciuti, 1969; Skarin, 1977), the age and physical features of the stranger (e.g., facial Gestalt, height) (Greenberg, Hillman, \& Grice, 1973; Lewis \& Brooks, 1974; Brooks \& Lewis, 1976; Weinraub \& Putney, 1978), the degree of experience the infant has had with multiple caretakers (Blehar, 1974, 1977; Harmon, Morgan, \& 
Klein, 1977; Ricciuti, 1974; Stevens, 1971), and the infant's level of irritability in general (Harmon et al., 1977).

One of the most conspicuous and perhaps central factors affecting stranger fear is the degree to which either the infant or stranger controls their encounters with one another. Studies emphasizing one or the other control dimension have been termed Infant-Controlled and StrangerControlled, respectively (Horner, 1980). All of the published longitudinal studies of infant stranger reactivity have employed a situation controlled by the stranger to elicit behavioral responses and emotional reactions. Thus, there is a bias on the part of these studies toward stimulating infants' capacities for ncgative affect reactivity rather than facilitating their endowed or acquired capacities to mitigate it. These studies have shown large individual differences in onset of the stranger aversive capacity. While an occasional infant may exhibit the capacity as early as the second quarter of the first year, the majority of infants begin to exhibit it during the third or fourth quarters (Bronson, 1972; Campos, Emde, Gaensbauer, \& Henderson, 1975; Emde, Gaensbauer, \& Harmon, 1976; Escalona, 1968; Gaensbauer et al., 1979; Schaffer \& Emerson, 1964; Tennes \& Lampl, 1964; Waters, Matas, \& Sroufe, 1975). Younger infants react more slowly than older infants to the stranger's presence and approach (Bronson, 1972, 1978). Institutionalization tends to delay the onset of the stranger fear capacity (Kagan, 1976; Provence \& Lipton, 1962), and there are conflicting accounts as to whether multiple caregivers enhance or mitigate the capacity (Blehar, 1977; Caldwell, 1963; Ricciuti, 1974: Stevens, 1971; Tizard \& Tizard, 1971).

Even at ages where Stranger-Controlled studies demonstrate considerable frequencies of negative stranger reactivity, Infant-Controlled studies (studies where the approach and regulation of distance between infant and stranger are in the control of the freely moving infant) have provided little evidence for a predominant status of fear in the 7- to 12-month-old infant (e.g., Bretherton \& Ainsworth, 1974; Corter, 1973; Eckerman \& Rheingold, 1974; Eckerman \& Whatley, 1975). This does not mean, of course, that there are not some infants for whom this is the case. But the typical pattern under Infant-Controlled conditions seems to be one of two relatively distinct affective-behavioral systems-one exploratory and social in nature, the other wary-somewhat in competition with each other (see Ainsworth, Blehar, Waters, \& Wall, 1978; Gaensbauer, Mrazek, \& Emde, 1979).

Wary or cautious behavior toward unfamiliar agemates seem to follow a developmental course that is slightly different from that characterizing behavior toward unfamiliar adults. Kagan, Kearsley, and Zelazo (1975) reported a developmental ascendence in behavioral inhibition and avoidance of unfamiliar peers that peaked at about 20 months. The inhib- 
itory tendency was stronger in non-day-care children. Proximity seeking of the mother was still high (highest, in fact) at 29 months. While at least some of the observed inhibition and looking behavior on the part of these toddler-aged children was no doubt simply a manifestation of orienting and curiosity, the pervasive patterns Kagan et al. observed, coupled as they were with heightened mother-proximity behavior, are strongly suggestive of a developmentally continuing capacity to be wary of unfamiliar persons. Whereas Kagan et al. averred that their data lent confirming support to Shirley's (1933) longitudinal observations of 25 young children, it is important to note that in at least one other study involving similarly aged infants this pattern has not been corroborated (Eckerman \& Whatley, 1977). ${ }^{2}$

In children beyond the second year of life, the specific variable of stranger reactivity is sometimes obscured by more global categories of social responsiveness, and many studies do not specifically address processes of acquaintanceship during the toddler years (e.g., Grief, 1977; Isaacs, 1933; Mueller \& Brenner, 1977; Mueller \& Lucas, 1975; Parten, 1932; Ralph, Thomas, Chess, \& Korn, 1968; Reuter \& Yunik, 1973; Shea, 1981; Whiteside, Busch, \& Horner, 1976). Individual case studies of toddler and preschool-aged children adapting to new situations and unfamiliar persons suggest that patterns of individual variation are broad (Murphy, 1962). Many studies of toddlers' and preschoolers' interactions with children and adults have produced data that seem to show that preschool-aged children display a manner of dealing with unfamiliar figures that is transitional between the infant pattern and adult pattern (Connolly \& Smith, 1972; Maccoby \& Feldman, 1972; Maudry \& Nekula, 1938; McGrew, 1972; Smith, 1974). Since these studies have not focused in detail upon the acquaintanceship process itself it is again impossible to delineate precisely the course of stranger reactivity during these years.

Sociological and ethological studies of adult-adult (stranger) encounters have defined patterns of behavior that, like those of the infant, effect either greater familiarization or dissociation. Perhaps the plainest evidence of stranger wariness and control derivatives in adult human inter-

\footnotetext{
2 Other studies of peer interactions have been either quite vague about the presence or absence of a specific fear/wariness dimension vis-a-vis peers (Field, 1979; Mueller \& Vandell, 1978; Young \& Lewis, 1978) or, being specific about its presence, uninformative of individual patterns of approach-avoidance with the unfamiliar peer (Bronson \& Panky, 1977). Of interest in the Bronson and Panky study, though, is their separation of wariness factors (predominantly inherent) from fear factors (predominantly acquired), a distinction that is of considerable value in the conceptualization of avoidance-aversive behavior in strange situations. The implication, of course, is that wariness as a trait is a function of neurophysiological/evolutionary predispositions, whereas fear traits develop as a function of noxious experiences.
} 
personal behavior resides in interaction rituals between unfamiliar persons with respect to their respective zones of personal space (see introductory section). Casual observations in natural behavior settings (e.g., elevators, bus stops, theater lobbies, study areas, public thoroughfares) typically reveal many behavioral (posture, gesture, vocalization-verbalization, etc.) and physical (clothing, objects, etc.) cues regulating space and interpersonal distance. (See Altman (1979) on privacy regulation.) The individual's "appearance" and "manner" are central among these (Goffman, 1958). It is in this regard that the direct correspondence between stranger reactivity and personal space phenomena is to be noted, and this will serve as a basis shortly for analyzing the developmental function of stranger wariness in infancy.

\section{Parameters of Stranger Wariness in Infancy}

According to reviews by Decarie (1974) and Emde et al. (1976), observations of and commentary on stranger anxiety or fearfulness in infants date from the previous century. In the modern era considerations of the functional significance of stranger fear begin with Hebb's (1946) theory of stimulus discrepancy and affect. Hebb's propositions dealt with the organism's reactions to discrepancies between novel external stimuli and internal (mental) representations, reactions that were said to be fearful when the discrepancy goes beyond comfortable limits. Despite knotty difficulties establishing meaningful quantitative measures of discrepancy and novelty (Lewis \& Brooks, 1974; Stone \& Church, 1973), the stimulus discrepancy theory has remained an essential part of contemporary thinking about wariness and interest (both being part of the arousal system) in the face of stimulus discrepancy and novelty (Hunt, 1961; Kagan, 1974; McCall \& McGhee, 1977; Schaffer, 1966; Sroufe et al., 1974). McCall \& McGhee (1977) have emphasized, for example, that internal states of subjective uncertainty frequently result in behavioral states of "motivaled inattention" (viz., Lacey, Kagan, Lacey, \& Moss, 1963). They cite the familiar experience of seeing someone that one cannot place turning away to recall (sort through) past images and impressions, and then attending to the present stimulus to see if recognition takes place. Schaffer $(1971,1974)$ spoke to the same process when he postulated stimulus - memory comparisons made by infants in the face of unfamiliar adults. Schaffer contrasted stimulus-memory comparisons (perceptual-cognitive matching) with stimulus-stimulus comparisons (percept-percept matching), linking the former with exploratory orientations to strangers and the latter with wary orientations.

Another category of explanation concerns the infant's emotional relationship with the caregiving environment, mainly the mother (or mother surrogate). Following Freud (1926), Spitz's (1950; Spitz \& Cobliner, 1965) 
conception which took direct note of perceptual-cognitive discrepancy factors, explained stranger fear as a function of the infant's experience of the mother as absent (lost) when the stranger is present. This point of view suffers greatly under the weight of evidence that indicates that short-term memory structures are sufficiently established during the developmental phases under consideration such that any sense of actual loss by the infant is barely conceivable. Spitz also believed that the specific phase of stranger anxiety constitutes a major shift both in the infant's relationship with its mother (toward a libidinal cathexis of her as whole object) and, as a consequence of this shift, its relationship with the social world beyond the mother. While this is quite plausible within the theoretical guidelines governing Spitz's thinking, this relationship has remained empirically undemonstrated.

Ethologically oriented theorists (c.g., Bowlby, 1969; Eibl-Eibesfeldt, 1980; Freedman, 1961; Gray, 1958; Szekely, 1954) have considered stranger fearfulness from the standpoint of innate defense reactions (flight mechanisms). Important to the problem under consideration, ethological interpretations have been based largely on observation of humans in natural settings and comparative analogy with animal behavior. However, data derived from controlled experimentation with human infants have lent strong support to the interpretation that particular stimulus configurations such as the height and facial Gestalt characteristics of the stranger have releasing significance with respect to the infant's behavioral turning from the stranger (Brooks \& Lewis, 1976; Freedman, 1961; Trause, 1977). Ethologically derived attachment theory (Ainsworth et al., 1978; Bowlby, 1969) forms the principal conceptual framework for viewing the infant's negative stranger reactions as manifestations of inherent defense mechanisms that involve the caregiver or other attachment figures as "havens of safety" for the fear-aroused infant.

Psychophysiological studies have generally supported the notion of a changing pattern of affective disposition toward unfamiliar persons during the first year of life. Campos et al. (1975; Campos, 1976) observed substantial shifts in the pattern of heartrate acceleration-deceleration related to stranger situations in infants studied at 5 and 9 months. Whereas younger infants generally show patterns of deceleration while in the presence of the stranger, suggesting a basic orientation to the stranger's appearance and presence (Graham \& Clifton, 1966; Lacey \& Lacey, 1970; Stechler \& Carpenter, 1967), older infants show patterns of acceleration (suggesting a defensive reaction), especially during moments when the stranger drew close to the infant (inside $1 \mathrm{~m}$ ). The accelerative response is magnified during the mother's absence from the encounter. While heartrate measures of acceleration-deceleration alone present some interpretive difficulties-they correspond to a large variety of simultaneously and 
sometimes divergent behavioral expressions of affect (Scarr-Salapatek, 1976) - the correspondence between changes in heartrate and behavioral experiences of avoidance and aversion on the one hand (acceleration) and alertness accompanied by behavioral wariness on the other (deceleration) is remarkably congruent in the Campos studies.

Sroufe et al. (1974) adduced psychophysiological data from 10-montholds' stranger reactions that are corroborative of Campos' findings. A greater degree of acceleration occurred in the laboratory (unfamiliar) environment than was the case in the infant's home. However, behavioral indices of negative reactivity were not congruent with the observed heartrate accelerative tendencics shown by infants. Despite what appeared in these data to be considerably broad variations from infant to infant with respect to the magnitude of heartrate acceleration a general trend in the unfamiliar setting was evident: the closer the stranger came, the greater the accelerative tendency seemed to be. This was only partly the case in the home setting. Similar findings have been reported by Waters et al. (1975).

The various treatments of stranger reactivity have generally emphasized its phase characteristics-that is, its crescendo, peak, and decline in the second half of the first year of life. Indeed, longitudinal data cited earlier support this phasic picture. Yet, when one looks across the span of develpment from infancy to adulthood (at least insofar as the empirical literature will allow) it becomes apparent that the stranger fear capacity, which has its onset in the first year of life, is a lifelong phenomenon the expressions and control of which, but not its specific nature, undergo transformations commensurate with transformations along other lines of development. ${ }^{3}$

\footnotetext{
${ }^{3}$ It is pertinent to refer to Erikson's ( 1963) first epigenetic stage of development, the stage of "trust vs mistrust." To most students of infancy, the main component of this polarity is the trust component. Indeed, in his two principal treatments of this epigenetic stage (1950, 1963) Erikson stated nothing concerning the importance of the capacity to mistrust in the overall adaptive functioning of the human subject. Too little, it seems, has been considered with respect to the mistrust component. Certainly, with respect to the mother and all significant others in the social environment the expectation and desired outcome is that the infant's capacity to trust will be nourished in order to furnish the developing self with a sense of rootedness and connectedness with human others. But there is also an importantindispensible, even-part played by the formation of a capacity to mistrust. In adulthood this capacity forms the nucleus of discernment in one's social relationships and, in specific regard to strangers, a preparedness for negative encounters. These dual capacities are firmly anchored in the neurophysiological constitution of living organisms (see, for example, Schneirla, 1959, 1965), being manifest as simple attraction-withdrawal mechanisms in the lesser developed species, and as more complex interaction rituals in more highly evolved species. In species where aggression occurs, whether instinctually endowed or learned, the capacity to mistrust in the service of protection from potential predators/injurers is adaptive.
} 


\section{PERSONAL SPACE: ANOTHER PARAMETER}

It is now my purpose to examine an apparent relationship between the encounter distance between infant and stranger and the infant's reaction to the stranger. Some of this has already been alluded to in the foregoing material. The reader should now recall the distinction that was made earlier between Infant-Controlled and Stranger-Controlled studies of infant-stranger encounters. Table 1 provides an overview of studies that have use Infant-Controlled methods of assessing stranger reactivity. ${ }^{4}$

Of the 323 subjects studied in this fashion approximately $28 \%$ have approached the stranger, usually within 4 to $5 \mathrm{ft}$. Because of different dala reporting practices it is unclear how close the infants actually have come in all instances. Nor is it possible to gauge fully the differing effects of varying interpersonal and toy configurations upon infant behavioral reactions. And even though the range of ages so studied most certainly indicates that differing locomotive abilities are represented throughout the sample, it is unlikely that very many infants included in the total survey in Table 1 (i.e., the eight 8-month-olds in the Rheingold \& Eckerman study) could not have crawled in the service of approach or avoidant motives. When physical contact with the stranger is examined it is obvious that a relatively small proportion (14\%) of infants have brought themselves near enough to touch the stranger. A glance at the durations of contact time on the part of infants who have made such contacts, however, reveals that such instances have been, when reported, few and highly transient. ${ }^{5}$

In view of hypotheses set forth in an earlier review of infant stranger reactivity (Horner, 1980) it is quite unlikely that these infants, who without overt evidence of apprehension approached or made actual contact with the stranger, experienced much in the way of distress laden affective arousal. It is also not unlikely that motivational forces comprised of curiosity (Berlyne, 1960) and associated interests (Izard, 1971), coupled with what may be considered to be distinct capacities on the part of the infant to tolerate and master (via active, exploratory means) the negative affective components of the situation, brought about the approach behaviors of the infants. We may presume that under such circumstances the infants perceptually and cognitively gauged the situation in a fashion analogous to hypothesis testing (Miller, Galanter, \& Pribram, 1960; Kagan, 1972, 1974; Schaffer, 1974) and that the multiple systems of be-

\footnotetext{
${ }^{4}$ Stranger-Controlled studies are not tabulated because they are quite uniform in their procedures and essential findings with respect to personal space (see text).

${ }^{5}$ Although we have not as yet quantified the data being acquired under Infant-Controlled conditions in our laboratory it is evidence that this pattern of limited affectively positive approaches toward and contact with the stranger also occurs in children in the second year of life.
} 
havioral responses available to the infant (see Ainsworth et al., 1978; Stern, 1974a) were governed by such operating mechanisms. But based on the data depicted in Table 1 there appears to be a definite trend on the part of infants (who in Infant-Controlled circumstances are presumably free from the anxiety producing elements of Stranger-Controlled conditions) toward maintaining some distance between themselves and the stranger. While the exact distance cannot be stated precisely, it can be reasonably speculated from the existing data that this distance is somewhere on the order of one to a few feet. Without specifying actual distances, it is reasonable to suppose that there is a zone surrounding either the infant or stranger (probably both) that possesses some signaling characteristic or set of related characteristics which in turn influences the behavior of the infant vis-a-vis the stranger.

Bretherton, Stolberg, and Kerye (1981) have recently reported InfantControlled findings from a study of 12-, 18-, and 24-month-olds under relatively extended ( $45 \mathrm{~min})$ toy-present, mother-present, two-strangerpresent conditions. The strangers were socially responsive but not initiating, using a 2.5 -ft distance measure of proximity. While they did not report wariness-fear findings, it is evident from their report that very little in the way of negative affect patterns occurred throughout the sample of infants studied. Over the three ages the average amount of proximity time (15-s intervals) ranged from 17.5 to $30.4(n=5)$ out of 180 possible such intervals. The amount of time spent in physical contact was much less, averaging 2.7 to 4.1 out of 180 possible intervals. There were no consistent trends in the temporal patterning of approaches toward the strangers except that at each successive interval of the observation sessions more of the infants had made their initial approaches to either of the strangers than in previous intervals. Incidentally, the degree of proximity between mother and strangers did not influence the rate of approach or contact between infants and the strangers. These authors concentrated their discussion of these findings on the differential contextual variables of responsive vs initiating stranger anxiety, but the possible mediating role played by personal space/self-boundary constructs could also be considered.

While under the Infant-Controlled conditions it is the geographic limit of infants' spontaneous, curiosity-motivated behaviors that suggests such a zone, under Stranger-Controlled conditions it is the infant's aversive behavior that suggests it. When data from Stranger-Controlled studies are perused it is evident that it is not the stranger's appearance but the stranger's approach that generally evokes negative affect in the infant. Moreover, it is a specific part of the approach that is evocative, that which entails the stranger's movement into the immediate surrounding space of the infant. This has been demonstrated behaviorally (Escalona, 1953; 
THOMAS M. HORNER

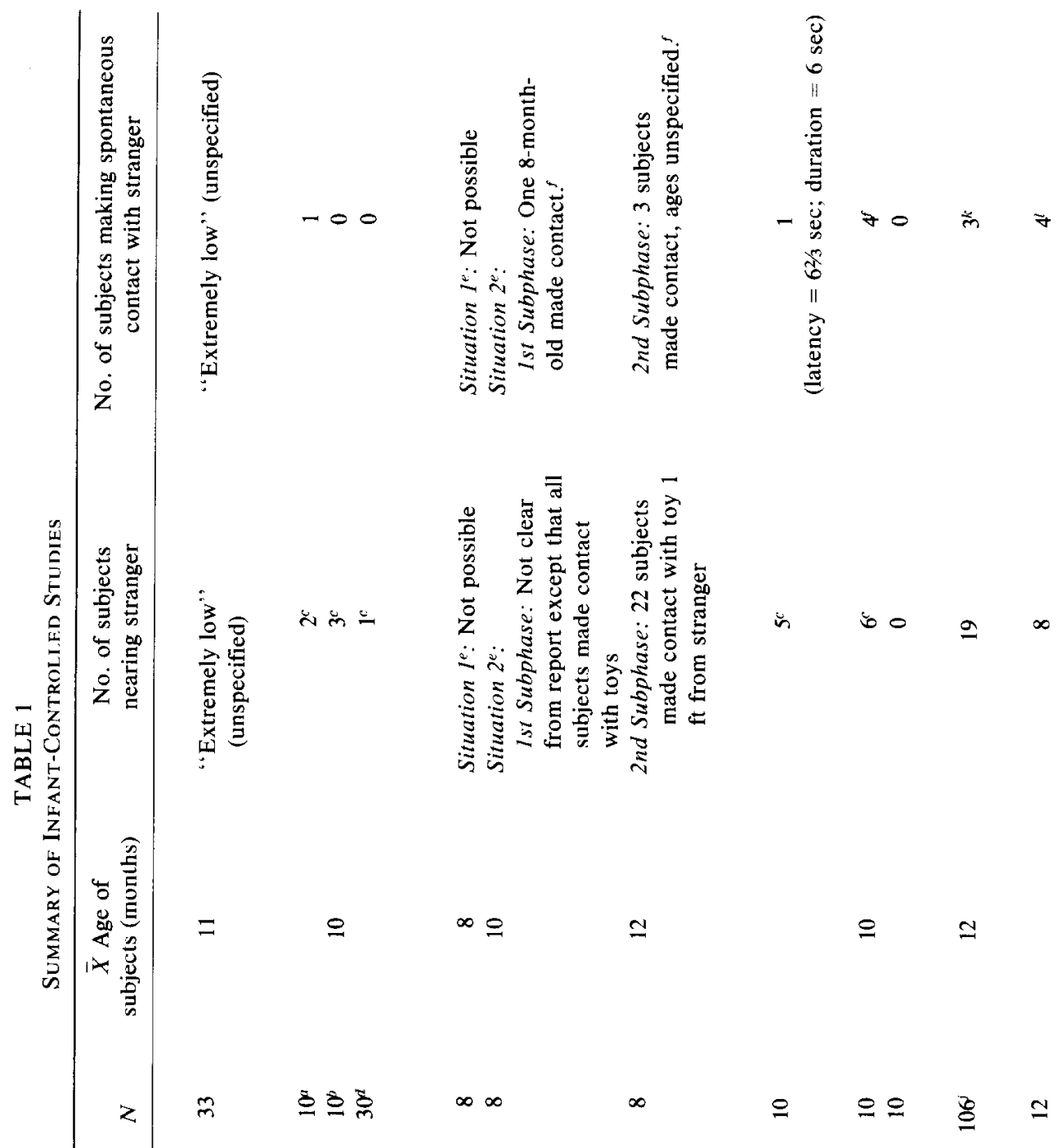

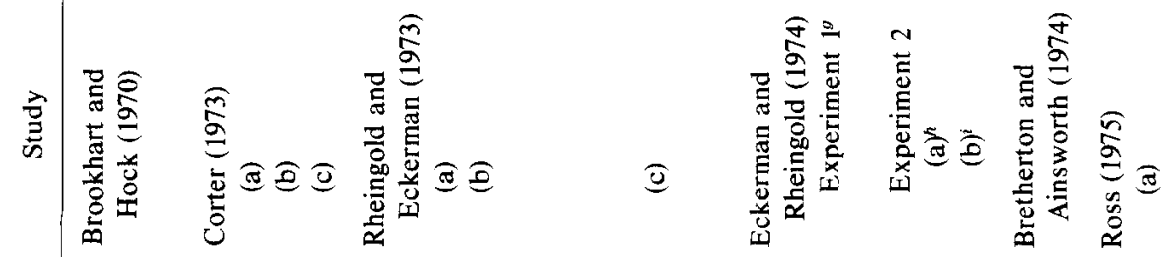




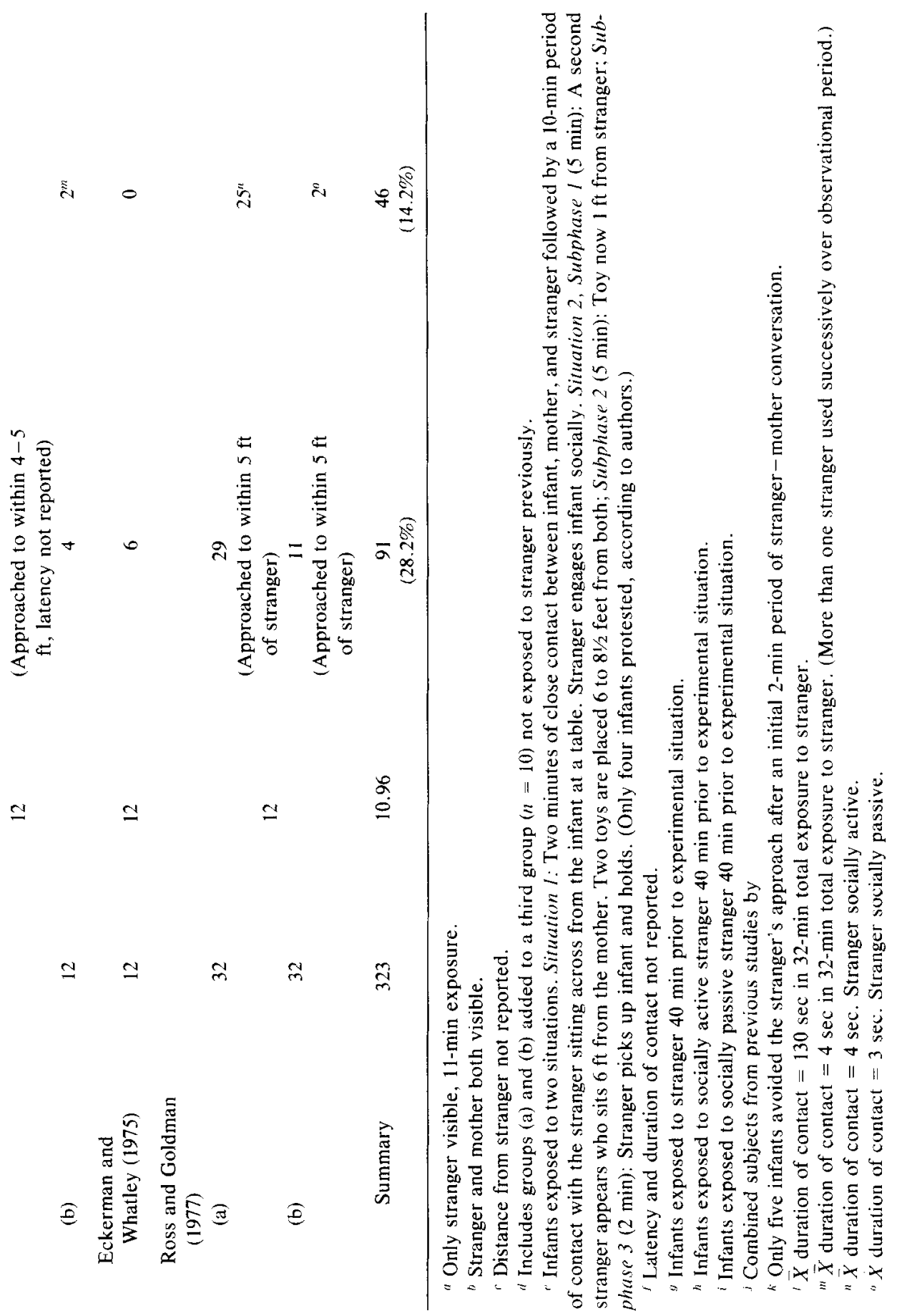


Morgan \& Ricciuti, 1969; Tennes \& Lampl, 1964) as well as physiologically via heartrate measures (Campos, 1976; Sroufe et al., 1974; Waters et al., 1975).

Personal space phenomena, then, are not difficult to locate in human infant behavior. The correspondence between infancy and adulthood with respect to empirical findings concerning stranger reactivity and personal space respectively is remarkably direct. Yet while there are substantial data to suggest the dynamic existence of personal space structures during the period of the first year of life, few have ever identified them as such. Campos et al. (1975; also Campos \& Stenberg, 1981) and Horner (1980) have made passing references to the possibility that personal space factors play some part in the reactions of infants toward approaching strangers. According to Horner,

\footnotetext{
When it is considered both that (1) a substantial majority of infants in InfantControlled studies have approached the stranger only up to a certain point short of physical contact, usually within four to five feet, and that (2) the final steps of Stranger-Controlled encounters, during which the stranger has intruded upon the immediate space surrounding the infant and then establishes physical contact, have generally produced demonstrable crudescences of behavioral . . . as well as physiological ... correlates of apprehension, it becomes apparent that some sort of critical distance or personal/self boundary factor may well be at work. (1980, p. 213)
}

In day-to-day life adults seem intuitively to sense this. In a unique study of adult behavior around an infant Shaffron (1974) produced evidence that adults tend to maintain some intcractive distance for a short time before invading the infant's immediate surrounding space.

The behavioral correlates of personal space seem quite similar in infancy and adulthood-only the degrees of response refinement and, of course, the subjective components that separate infancy from adulthood in general distinguish them. This leaves, then, the question of whether or not the behavioral phenotype that spans development in such a continuous manner is in any way anchored in a genotype that also functions continuously throughout development (see, for example, Kagan, 1969). This question in turn raises issues that lie on treacherous ground for the theoretician; issues, for example, that concern phenomenological components of infant behavior. Moreover, the reader must keep in mind that the behavioral resemblances existing between the behavior patterns of infants and adults within a given species-especially within humans where the developmental pathways from neonancy to maturity are so varied, complex, and open-can rarely be ascribed better than analogous status, to use an evolutionary term. In the case of the personal space phenomena I am considering the minuteness of resemblance (viz., Simpson, 1961) - that is, point to point correspondence between them- 
that is required for what the evolutionist would call a homology must still be determined. Formal (that is, behavior-morphic) analysis of the stranger reactive patterns of humans across the span of development suggest that the homology may be there. We may at least consider a condition of what Hodos (1976) has termed behavioral homoplasy, defined as

[b]ehaviors that are similar but that cannot be related to structures that can, in principle, be traced back through a genealogical series to a stipulated common ancestral precursor. (p. 159)

In the present instance, common ancestral precursor must properly be replaced by common developmental situation or function. To further use Hodos' model, we might expect that to the extent that infant an adult stranger-reaction behavior patterns are similar in a homplastic sense, the underlying process is one of convergence - that is, one whereby environmental presses operate similarly to produce similar behavioral adaptations. (For further discussions of the problem of homology see Masterton, Hodos, \& Jerison (1976).)

\section{THEORETICAL CONSIDERATIONS AND EMPIRICAL PATHWAYS}

With, then, the identification of possible personal space phenomena in human infancy it is reasonable to postulate that their onset signals a major shift in the organization of the infant's experience of self. Far from being conscious in a literal manner of its self, the infant nonetheless acts as though it has a sense of self operating within the interpersonal context surrounding it. ${ }^{6}$ While many of the infant's behaviors during the midportion of the first year of life, including imitation, contingency play, social interaction play, and mirror play (see, for example, Call, 1968; Kleeman, 1967;

${ }^{\mathrm{i}}$ I fully acknowledge that an infant acting as though it is governed by a motive state which resembles adult action referable to the same motive is no proof of its actually being caused by the same motive state. While this point is perhaps moot by virtue of its wide acceptance among behavioral scientists, in the service of creating a proper perspective for the speculations I wish to make, it perhaps still deserves this brief mention. The issue is further addressed by Kagan (1969) and, more recently, by Wohlwill (1980), both of whom formulate the issue in terms of homotypic versus heterotypic variations in behavior-motive constellations. Basically, they discuss the dilemmas that are encountered in establishing patterns of temporal continuity when it is known both that specific behaviors may serve different motive states and that specific motive states may he asociated with different behaviors over even relatively short periods of development. (See, for example, a pertinent application of this principle in comparisons of stranger activity behavior in infants across the first year of life (Bronson, 1974).) The gap between the abundant empirical data with respect to the interpersonal spatial behavior of infancy and adulthood is broad despite some interesting but incomplete data for intermediate periods of development (see below). Thus, I shall have to confine my speculations to a framework that regards, in evolutionary terms at least, the respective processes to be discussed as at best analogous rather than homologous (cf. von Cranach, 1972). 
Lewis \& Brooks-Gunn, 1979; Mahler et al., 1975; Stern, 1974b), are indicative of advances made in the domain of the self, the complex of behaviors that are associated on the one hand with personal space and on the other hand with self-boundaries may herald a coalescence of selfrepresentations that comprises the core of subjectivity around which will evolve higher order systems of affect, perception, and cognition. (See Trevarthen (1977) and Newson (1977) for further interesting and evocative theoretical considerations of early subjectivity.) Implied by this is a subjective state of self that is coherent (in an inchoate way) and distinct (representationally speaking) from the social world. ${ }^{7}$ Mahler et al. (1975) describe behavioral and emotional interactions between the infant and others (especially the mother) that connote the formation of a selfstructure demarcated by self-boundaries. These include the pleasurable kinesthetic and tactile stimulations that are created through motor activity such as kicking and flailing, crawling, walking, and so forth; playful behavioral interchanges centering upon the body and its parts ("This is my nose, where is your nose?" "pat-a-cake," "so big," etc.), and tactile encounters with objects through bumping, falling, play, etc.-all of which further augment body - self boundaries. Peek-a-boo play seems to be especially important, serving what Mahler et al. believe to be

\footnotetext{
7 The idea that prior to that point in development when the self is experienced as being distinct from others there is a phase in which the infant's experiences of self and other are blended, confused, and symbiotically one, is central to psychoanalytic developmental psychology (e.g., Jacobson, 1964; Mahler, Bergman, \& Pine, 1975) and the quasidevelopmental psychology of Kohut (1977). As part of a general critique of psychoanalytic infant psychology Peterfreund (1978) brought the issue of the symbiotic unity of the self and object into question, citing it as one of the basic fallacies in psychoanalytic thinking concerning this period in development. Agreeing with this particular criticism of self psychology, I recommend a view of the pre-self-distinguished-from-object phase as one best defined in terms of the lack of unity of experience rather than in the terms of an undifferentiated structure of self-object. This, of course, is not to say that certain psychological and personality conditions are not organized within a psychodynamic framework wherein the distinctions made by the individual, between aspects of the self and the other are blurred (as, for example, in the case of some narcissistic characterological formations and certain borderline personality configurations where heavy degrees of projective identifications with others occur (see Kernberg, 1975; Masterson, 1981).) However, nothing in the theories concerning these clinical entities requires a postulation of symbiotic unity prior to the phase in which behavioral distinctions on the part of the infant between self and other can be observed. A better approach to conceptualization this earlier period, I believe, is provided by the constructivist psychology of Piaget. Accordingly, the object can be viewed in terms of a mental representational system that is constructed to organize experience, and in which objects (others) become distinguished according to attributes discovered by the infant to be independent of its subjectivity and its intentionality (Horner, in preparation). It is important, therefore, to keep in mind that differentiation between self and object is not necessarily meant in the paper to connote a predifferentiation phase in human development entailing the experience of self and object as one.
} 
a double purpose--to find mother, but also to be found by her. To be found by mother, to be seen by her (that is to say, mirrored by her) seems to build body self awareness which we must surmise from observation of the endless pleasure in this repetitive game. (1975, p. 221-222).

These inferences parallel inferences drawn by Spitz and Cobliner (1965), who also tacitly linked stranger fear phenomena with "integration and structuration of the newly established ego [and] ... its boundaries through action exchanges"' (p. 163) with the object world.

It is . . clear from the behavioral changes of the child that the ego has greatly changed from the rudimentary ego achieved at three months. It has developed a series of systems, like memory, perception, the thought processes, the faculty of judgment ... and ego apparatuses like the understanding of space, the social gesture, a little later the capacity for locomotion, all of which make the ego more effective, but also a more complex structure. We can say that now the ego [self] has come into its own. (Spitz, 1959, p. 42)

These developments are echoed by those who have written more specifically in terms of the infant's evolving "competence." Here the emphasis is on the infant's emerging capacity for feelings of efficacy (White, 1959), argued by Goldberg (1977) and Duck, Miell, and Goebler (1980), respectively, to be a central mediating component of reciprocity in childhood as well as adult social relationships. It entails the sense that systematically discovered contingencies of one's behavior exist in the world of social interchange (Levitt, 1979; Lewis \& Goldberg, 1969; Watson, 1972) and actions on objects (Gunnar-Vongnechten, 1978; Piaget, 1952; White, 1971, 1975). With the capacities to intend and to monitor contingency sequences that are developed during the first year the infant's sense and mental representation of self expand rapidly, affecting significant developments in communication patterns and language acquisition (Bruner, 1975a, 1975b). As development proceeds, the child's continual experience of the boundaries between self and other are the somewhat forceful basis of its gradual and slow progress away from egocentric thinking (Piaget, 1929).

Essential to competence are the cognitive factors underlying self -other distinctions. Based on empirical studies, Lewis and Brooks-Gunn (1979) have distinguished four phases of self-development in the first 2 years of life, two of which pertain to the period in which personal space and self-boundary phenomena arise. In the 3-to 8-month phase they describe a state of self wherein elaborate action-outcome pairings (or cognitions) parallel distinctions between self and other that is consolidated but fleeting for lack of a notion of permanence. In the 8- to 12-month phase, however, they describe a process of consolidation of self-other distinctions that is entirely compatible with the idea that specific boundary representations come into effect as mediators of the personal space phenomena that make their appearance during this development period. 
Two avenues of investigatory activity are both suggested by and crucial to the validation of the considerations that have been made to this point. The first avenue entails further descriptions and experimental manipulations of personal space factors in infants, and points toward establishing personal space as a significant mediating variable in infant behavior and, presumably, emotional expression. It also directs attention toward the relationships between personal space as a social developmental milestone and other established milestones (e.g., social smiling, stranger reactivity, peer interaction). The second avenue entails the use of refined behavioral methods to make systematic comparisons of personal space behavior over the course of development, and points toward the possibility of establishing personal space as a significant area of continuity in life. The relevant vehicle of travel along these avenues is, of course, the variable of proximity that is sought, maintained, or avoided by the child in its interactions and contacts with others. This variable is a familiar one in developmental research, particularly that which is ethologically focused. Social-demographic and psychological factors associated with this variability (e.g., gender, familiarity, status, aggressivity) are important covariates to consider.

Questions of immediate interest concern primarily the dynamics of personal space within larger situational (see, for example Endler, 1977; Magnusson, 1981; Mischel, 1973; Volkert, 1951) and emotional (Sorce \& Emde, 1981; Sroufe, Waters, \& Matas, 1974) contexts as well as the functions of personal space in various situations (e.g., its impact on the shape of situations (see Snyder, 1981).)

In the author's own research activities a series of studies is about to be commenced which will examine certain aspects of personal space behavior in parent-infant dyads in strange situations (laboratory), including intrusions made by the parent or stranger during structured and unstructured interactions. These studies will also focus on antecedents of personal space behavior. The stranger reactivity studies that have been included in this essay bear many implications for more detailed study (both naturalistic and manipulatory) of personal space. Many of these pertain to questions of immediate interest: How does personal space fluctuate with, for example, parental availability, prior to experience with others, the child's familiarity with the environment, the specific behaviors of others? Organizational and ecological questions are ready to be addressed. For example, how do others treat the personal space of the infant. (See, in this light, proach styles of 15 adults who were meeting a single infant for the first time. This study showed that most adults do in fact show a regard for what can be presumed to be the personal space of the infant). As others' behaviors towards the infant begin to reflect a regard for its personal space, 
what are the correlates in the infant's own reactivity to intrusions and, on the other side of the coin, in the infant's movements in the presence of others? Are home, day-care, and laboratory environments constructed in ways that acknowledge or presume the existence of personal space factors in infants and young children?

Clearly, there is a phenomena of personal space originating in infancy. It is marked by the patterns of stranger reactivity that have been described. It seems safe to assert that the various patterns of stranger reactivity that can be observed at infancy and adulthood respectively belong to the same continuum of interpersonal responding and behavioral regulation. Considerations of personal space and self boundary formation in infancy from the separate perspectives of the social-interactional and intrapsychic phenomena to which they refer substantially reinforce the utility and validity of these theoretical constructs. They are higher overlapping in scope of behavior to which they refer. Yet they are distinct in the very different ways they refer to similar behavioral processes. Together they offer a framework for bringing together integratively two higher order domains of theory (sociological and intrapsychic) in ways that are too often overlooked or disregarded.

\section{REFERENCES}

Aiello, J. D., \& Jones, S. E. Field study of the proxemic behavior of young children in three subcultural groups. Journal of Personality and Social Psychology, 1971, 19, 351-56.

Ainsworth, M. D. S., Blehar, M. C., Waters, E., \& Wall, S. Patterns of attachment. Hillsdale, N.J.: Erlbaum, 1978.

Altman, I. Ecological aspects of interpersonal functioning. In A. H. Esser (Ed.), Behavior and environment. New York: Plenum, 1971. pp. 291-306.

Altman, I. Privacy as an interpersonal boundary process. In M. von Cranoch, K. Foppa, W. Lepenies, \& D. Ploog (Eds.), Human ethology. New York: Cambridge Univ. Press, 1979. Pp. $95-132$.

Ambrose, J. A. The concept of a critical period for the development of social responsiveness in early human infancy. In B. M. Foss (Ed.), Determinants of infant behavior (Vol. 2). New York: Wiley, 1963, Pp. 201-25.

Argyle, M. Bodily communication. New York: International Universities Press, 1975.

Ashcraft, N., \& Scheflen, A. E. People space. New York: Anchor, 1976.

Baldassare, M. Human spatial behavior. Annual Review of Sociology, 1978, 29-56.

Barrera, M. E., \& Maurer, D. The perception of facial expression by the three-month-old. Child Development, 1981, 52, 203-207.

Barrera, M. E., \& Maurer, D. Discrimination of strangers by the three-month-old. Child Development, 1981, 52, 550-63. (b)

Batter, B. S., \& Davidson, C. V. Wariness of strangers: Reality or artifact? Journal of Child Psychology and Psychiatry, 1979, 20, 93-109.

Bayley, N. The Bayley Scales of Infant Development. New York: Psychological Corp., 1969.

Berger, C. R., \& Calabresc, R. J. Some explorations in initial interaction and beyond: To- 
ward a development theory of interpersonal communication. Human Communication Research, 1975, 1, 99-112.

Berlyne, D. E. Conflict, arousal, and curiosity. New York: McGraw-Hill, 1960.

Blatt, S., \& Wild, C. A. Schizophrenia: A developmental analysis. New York: Academic Press, 1976.

Blehar, M. C. Anxious attachment and defensive reactions associated with day care. Child Development, 1974, 45, 683-92.

Blehar, M. C. Mother-child interaction in day-care and home-reared children. In R. A. Webb (Ed.), Social development in childhood: Day-care programs and research. Baltimore: Johns Hopkins Press, 1977. Pp. 1-33.

Bowlby, J. Attachment and loss, Vol. 1, Separation. London: Hogarth Press, 1969.

Brackbill, Y., and Koltsova, M. M. Conditioning and learning. In Y. Brackbill (Ed.), Infancy and early childhood. New York: Free Press, 1967. Pp. 207-87.

Bretherton, I., \& Ainsworth, M. D. S. Responses of one-year-olds to a stranger in a strange situation. In M. Lewis \& L. A. Rosenblum (Eds.), The origins of fear. New York: Wiley, 1974. Pp. 131-64.

Bretherton, I., Stolberg, U., \& Kreye, M. Engaging strangers in proximal interaction: Infants' social initiative. Development Psychology, 1981, 17, 746-755.

Brody, S., \& Axelrad, S. Anxiety and ego formation in infancy. New York: International Universities Press, 1970.

Bronson, G. W. Infants' reactions to unfamiliar persons and novel objects. Monographs of the Society for Research in Child Development, 1972, 37 (3, Serial No. 148).

Bronson, G. W. Teneral issues in the study of fear. In M. Lewis \& L. A. Rosenblum (Eds.), The origins of fear. New York: Wiley, 1974. Pp. 254-258.

Bronson, G. W. Aversive reactions to strangers: A dual process interpretation. Child Development, 1978, 49, 495-499.

Bronson, G. W., \& Panky, W. B. On the distinction between fear and wariness. Child Development, 1977, 48, 1167-1183.

Brooks, J., \& Lewis, M. Infants' responses to strangers: Midget, adult, and child. Child Development, 1976, 47, 323-332.

Brooks-Gunn, J., \& Lewis, M. Infant social perception: Responses to pictures of parents and strangers. Developmental Psychology, 1981, 17, 647-649.

Bruner, J. From communication to language-A psychological perspective. Cognition, $1975,3,255-287$. (a)

Bruner, J. The ontogenesis of speech acts. Journal of Child Language, 1975, 2, 1-19. (b)

Burgoon, J. K., \& Jones, S. B. Toward a theory of personal space expectations and their violations. Human Communication Research, 1976, 2, 131-146.

Caldwell, B. Mother-infant interactions in monomatric and polymatric families. American Journal of Orthopsychiatry, 1963, 33, 653-664.

Call, J. D. L.ap and finger play in infancy, implications for ego development. International Journal of Psychoanalysis, 1968, 49, 375-378.

Campos, J. J. Heart rate: A sensitive tool for the study of emotional development in the infant. In L. P. Lipsitt (Ed.), Developmental Psychobiology. Hillsdale, N. J.: Erlbaum, 1976. Pp. 1-31.

Campos, J. J., \& Stenberg, C. R. Perception, appraisal and emotion: The onset of social referencing. In M. E. Lamb \& L. R. Sherrod (Eds.), Infant social cognition: The onset of social referencing. Hillsdale, N. J.: Erlbaum, 1981. Pp. 273-314.

Campos, J. J., Emde, R. N., Gaensbauer, T., \& Henderson, C. Cardiac and behavioral interrelationships in the reactions of infants to strangers. Developmental Psychology, $1975,11,589-601$. 
Carpenter, G. Mother's face and the newborn. In R. Lewis (Ed.), Child alive! New York: Doubleday, 1975.

Comolly, K., \& Smith, P. K. Reactions of pre-school children to a strange observer. In N. B. Jones (Ed.), Ethological studies of child behavior. New York: Cambridge Univ. Press, 1972. Pp. 157-174.

Corter, C. A comparison of the mother's and stranger's control over the behavior of infants. Child Development, 1973, 44, 703-713.

Dean, L. M., Willis, F. N., \& IaRocco, S. M. Invasion of personal space as a function of age, sex, and race. Psychological Reports, 1976, 38, 959-65.

Decarie, T. G. The Infant's reactions to strangers. New York: International Universities Press, 1974.

Dixon, S. D., Yogman, M., Tronick, E., Adamson, L., Als, H., \& Brazelton, T. B. Early infant social interaction with parents and strangers. Joumal of the American Academy of Child Psychiatry, 1981, 20, 32-52.

Duck, S., Miell, D. K., \& Gaebler, H. C. Attraction and communication in children's interactions. In H. C. Foot, A. J. Chapman, \& J. R. Smith (Eds.), Friendship and social relations in children. New York: Wiley, 1980. Pp. 89-115.

Eckerman, C. O., \& Rheingold, H. Infants' exploratory responses to toys and people. Developmental Psychology, 1974, 2, 225-259.

Eckerman, C. O., \& Whatley, J. L. Infants' reactions to unfamiliar adults varying in novelty. Developmental Psychology, 1975, 11, 562-566.

Eckerman, C. O., \& Whatley, J. L. Toys and social interaction between infant peers. Child Development, 1977, 48, 1645-1656.

Edney, J. J. Human territoriality. Psychological Bulletin, 1974, 81, 959-975.

Eibl-Eibesfeldt, I. Strategies of social interaction. In R. Plutchik \& H. Kellerman (Eds.), Emotion: Theory, research and experience, Vol. I, Theories of emotion. New York: Academic Press, 1980. Pp. 57-59.

Emde, R. N., Gaensbauer, T. J., \& Harmon, R. J. Emotional expression in infancy: A biobehavioral study. Psychological Issues, 1976, 10 (Monograph No. 37).

Endler, N. S. The role of person-by-situation interactions in personality theory. In I. C. Uzgiris \& F. Weizmann (Eds.), The structuring of experience. New York: Plenum, 1977. Pp. $343-369$.

Erikson, E. H. Growth and crises of the healthy personality. In M. J. E. Senn (Ed.), Symposium on the healthy personality, Suppl. II, Problems of infancy and childhood. New York: Josiah Macy, Jr., Foundation, 1950. Pp. 91-146.

Erikson, E. H. Childhood and society. New York: Norton, 1963. 2nd ed.

Escalona, S. Emotional development in the first year of life. In M. J. E. Senn (Ed.), Transactions of the Sixth Conference on Problems of Infancy and Childhood. New York: Josiah Macey, Jr., Foundation, 1953. Pp. 11-92.

Escalona, S. The roots of individuality. Chicago: Aldine, 1968.

Evans, G. W., \& Howard, R. B. Personal space. Psychological Bulletin, 1963, 80, 334-344.

Federn, P. Ego psychology and the psychoses. New York: Basic Books, 1952.

Field, T. M. Infant behaviors directed toward peers and adults in the presence and absence of mother. Infant Behavior and Development, 1978, 2, 47-54.

Fisher, R. L. Social schemas of normal and disturbed children. Journal of Educational Psychology, 1967, 58, 88-92.

Fisher, S. Body experience in fantasy and behavior. New York: Appleton-Century-Crofts, 1970.

Fisher, S., \& Cleveland, S. E. Body image and personality. New York: Dover, 1968.

Fitzgerald, H. E. Autonomic pupillary reflex activity during early infancy and its relation to social and nonsocial visual stimuli. Journal of Experimental Child Psychology, 1968, 6, $470-482$. 
Fredericks, J. A. M. Disorders of the body schema. In P. J. Vinken \& G. W. Bruyn (Eds.), Handbook of clinical neurology (Vol. 4). New York: Wiley, 1969, 207-240.

Freedman, D. G. The infant: Fear of strangers and the flight response. Journal of Child Psychology and Psychiatry, 1961, 2, 242-248.

Freeman, T., Cameron, J. L., \& McGhie, A. Chronic schizophrenia. London: Tavistock, 1958 .

Freud, S. Inhibitions, symptoms, and anxiety (1976). In J. Strachey (Ed.), Standard edition of the complete psychological works of Sigmund Freud (Vol. 20). London: Hogarth Press, 1959, 87-172.

Gaensbauer, T. J., Emde, R. J., \& Campos, J. J. Stranger distress: Confirmation of a developmental shift in a longitudinal sample. Perceptual and Motor Skills, 1976, 12, 99- 106.

Gaensbauer, T. J., Mrazek, D., \& Emde, R. N. Pattering of emotional response in a playroom laboratory situation. Infant Behavior and Development, 1979, 2, 163-178.

Gewirtz, J. L. The course of infant smiling in four child-rearing environments in Israel. In B. M. Foss (Ed.), Determinations of infant behavior (Vol. 3). London: Methuen, 1965. Pp. 205-261.

Goffman, E. The presentation of self. New York: Doubleday, 1958.

Goffman, E. Behavior in public places. New York: Free Press, 1963.

Goffman, E. Interaction ritual. New York: Doubleday, 1967.

Goffman, E. Relations in public. New York: Harper, 1971.

Goldberg, S. Social competence in infancy: A model of parent-infant interaction. MerrillPalmer Quarterly, 1977, 23, 162-177.

Graham, F. K., \& Clifton, R. Heart-rate change as a component of the orienting response. Psychological Bulletin, 1966, 65, 305-320.

Gray, P. H. Theory and evidence of imprinting in human infants. Journal of Psychology, $1958,46,155-168$.

Greenberg, D. J., Hillman, D., \& Grice, D. Infant and stranger variables related to stranger anxiety in the first year of life. Developmental Psychology, 1973, 9, 207-212.

Greif, E. B. Peer interactions in preschool children. In R. A. Webb (Ed.), Social development in childhood: Day-care programs and research. New York: Johns Hopkins, 1977. Pp. $141-160$.

Guardo, C. J. Personal space in children. Child Development, 1969, 40, 143-151.

Gunnar-Vongnechten, M. R. Changing a frightening toy into a pleasant toy by allowing the infant to control its actions. Developmental Psychology, 1978, 14, 157-162.

Hall, E. T. Silent assumptions in vocal communication. In D. Rioch \& E. A. Weinstein, (Eds.), Disorders of communication. Baltimore: Williams \& Wilkins, 1964.

Hall, E. T. The hidden dimension. New York: Doubleday, 1966.

Harmon, R. J., Morgan, G. A., \& Klein, R. P. Determinants of normal variation in infants' negative reactions to unfamiliar adults. Journal of the American Academy of Child Psychiatry, 1977, 16, 670683.

Hayduck, L. A. Personal space: An evaluative and orienting review. Psychological Bulletin, $1978,85,117-134$.

Hebb, D. O. On the nature of fear. Psychological Review, 1946, 53, 259-276.

Hodos, W. The concept of homology and the evolution of behavior. In R. B. Masterson, W. Hodos, \& H. Jerison (Eds.), Evolution, brain, and behavior: Persistent problems. Hillsdale, N. J.: Erlbaum, 1976. Pp. 153-167.

Horner, T. M. Piagetian concepts and the self. In preparation.

Horner, T. M. Two methods of studying stranger reactivity in infants: A review. Journal of Child Psychology and Psychiatry, 1980, 21, 203-219.

Horner, T. M., Windisch, W., \& Solyom, A. Two prototypes of ambivalence in infancy. In preparation.

Hunt, J. M. Intelligence and experience. New York: Ronald, 1961. 
Ihara, $\mathrm{N}$. The development of personal space in Japanese children. Journal of Child Development, 1978, 14, 42-51.

Isaacs, S. Social development in young children. New York: Harcourt Brace, 1933.

Izard, C. The face of emotion. New York: Appleton-Century-Crofts, 1971.

Jacobson, E. The self and the object world. New York: International Universities Press, 1964.

Kagan, J. The three faces of continuity in human development. In D. A. Goslin (Ed.), Handbook of socialization theory and research. Chicago: Rand McNally, 1969. Pp. 983-1002.

Kagan, J. Discrepancy, temperament, and infant distress. In M. Lewis \& L. A. Rosenblum (Eds.), The origins of fear. New York: Wiley, 1974. Pp. 229-248.

Kagan, J. Resilience and continuity in psychological development. In A. M. Clarke \& A. B. D. Clarke (Eds.), Early experience: Myth and evidence. London: Open Books, 1976. Pp. 97-121.

Kagan, J., Kearsley, R. B., \& Zelazo, P. R. The emergence of initial apprehension to unfamiliar peers. In M. Lewis \& L. A. Rosenblum (Eds.), Friendship and peer relations. New York: Wiley, 1975. Pp. 187-206.

Kasatkin, N. I. The origin and development of conditional reflexes in childhood. In M. Cole \& I. Maltzman (Eds.), Handbook of contemporary Soviet psychology. New York: Basic Books, 1968.

Kernberg, O. Borderline conditions and pathological narcissism. New York: Aronson, 1975.

Kessen, W., Haith, M. M., \& Salapatek, P. H. Human infancy: A bibliographic guide. In P. H. Mussen (Ed.), Carmichael's manual of child psychology, 3rd ed., Vol. 1. New York: Wiley, 1970. Pp. 287-446.

Kleeman, J. The peek-a-boo game. Part I. Its origins, meanings and related phenomena in the first year. Psychoanalytic Study of the Child, 1967, 22, 239-273.

Kohut, H. The restoration of the self. New York: Intern. Univ. Press, 1977.

Lacey, J. I. \& Lacey, B. C. Some autonomic-central nervous system interrelationships. In P. Black (Ed.), Physiological correlates of emotion. New York: Academic Press, 1970. Pp. 205-228.

Lacey, J. I., Kagan, J., Lacey, B. C., \& Moss, H. I. The visceral level: Situational determinants and hehavioral correlates of autonomic response patterns. In P. H. Knapp (Ed.), Expression of the emotions in man. New York: Intern. Univ. Press, 1963. Pp. 161-196.

Landis, B. Ego boundaries. Psychological lssues, 1970, 6 (Monograph No. 24).

Levitt, M. J. The effect of response contingent feedback on infants' reactions to a stranger. Paper presented at the meeting of the Society for Research in Child Development, March 1979.

Lewin, K. Principles of topological psychology. New York: McGraw-Hill, 1936.

Lewis, M., \& Brooks-Gunn, J. Social cognition and the acquisition of self. New York: Plenum, 1979.

Lewis, M., \& Goldberg, S. Perceptual-cognitive development in infancy: A generalized expectancy model as a function of the mother-infant interaction. Merrill-Palmer Quarterly, 1969, 15, 81-100.

Lewis, M., \& Rosenblum, L. A. (Eds.), The origins of fear. New York: Wiley, 1974.

Lidz, T. The origin and treatment of schizophrenic disorders. New York: Basic Books, 1973.

Loo, C., \& Smetana, J. The effects of crowding on behavior and perception of 10-year-old boys. Environmental Psychology and Nonverbal Behavior, 1978, 2, 226-249.

Maccoby, E. E., \& Feldman, S. S. Mother-attachment and stranger-reactions in the third 
year of life. Monographs of the Society for Research in Child Development, 1972, 37 (1, Serial No. 146).

MacFarlane, J. A. Olfaction in the development of social preferences in the human neonate. In Parent-infant interaction. CIBA Foundation Symposium No. 33. New York: Associated Scientific Publishers, 1975. Pp. 103-112.

Magnusson, E. (Ed.) Toward a psychology of situations: An interactional perspective. Hillsdale, N.J.: Erlbaum, 1981.

Mahler, M., Pine, F., \& Bergman, A. The psychological birth of the human infant. New York: Basic Books, 1975.

Mallenby, T. W. Personal space: Direct measurement techniques with hard-of-hearing children. Environment and Behavior, 1974, 6, 117-122.

Masterson, J. F. The narcissistic and borderline conditions. New York: Brunner/Mazel, 1981.

Masterson, R. B., Hodos, W., \& Jerison, H. Evolution, brain, and behavior: Persistent problems. Hillsdale, N.J.: Erlbaum, 1976.

Maudrey, M., \& Nekula, M. Social relations between children of the same age during the first two years of life. Journal of Genetic Psychology, 1939, 54, 193-215.

McCall, R. B., \& McGhee, P. E. The discrepancy hypothesis of attention and affect in infants. In I. C. Uzgiris \& F. Weizmann (Eds.), The structuring of experience. New York: Plenum, 1977. Pp. 179-210.

McGrew, W. L. Aspects of social development in nursery school children, with emphasis on introduction to the group. In N. B. Jones (Ed.), Ethological studies of child behavior. New York: Cambridge Univ. Press, 1972. Pp. 129-156.

Meisels, M., \& Guardo, C. J. Development of personal space schemata. Child Development, 1969, 40, 1167-1178.

Mettler, F. A. Structural basis of the self. New York Academy of Sciences, 1962, 96, $687-728$.

Miller, G., Galanter, E., \& Pribram, K. Plans and the structure of behavior. New York: Holt, Rinehart \& Winston, 1960.

Miller, J. G. Living systems: Basic concepts. Behavioral Science, 1965, 10, 193-237.

Mischel, N. Toward a cognitive social learning reconceptualization of personality. Psychological Review, 1973, 80, 252-283.

Morgan, G., \& Ricciuti, H. Infants' responses to strangers during the first year. In B. M. Foss (Ed.), Determinants of infant behavior (Vol. 4). London: Methuen, 1969. Pp. $253-272$.

Mueller, E., \& Brenner, J. The origins of social skills and interaction among playground toddlers. Child Development, 1977, 48, 854-861.

Mueller, E., \& Lucas, J. A developmental analysis of peer interaction among toddlers. In M. Lewis \& L. A. Rosenblum (Eds.), Friendship and peer relations. New York: Wiley, 1975. Pp. 223-258.

Mueller, E., \& Vandell, D. L. Infant-infant interaction. In J. Osofsky (Ed.), Handbook of infant development. New York: Wiley, 1979. Pp. 591-622.

Murphy, L. B. The widening world of childhood. New York: Basic Books, 1962.

Newson, J. An intersubjective approach to the systematic description of mother-infant interaction. In H. R. Schaffer (Ed.), Studies in parent-infant interaction. New York: Academic Press, 1977. Pp. 47-61.

Parten, M. B. Social participation among pre-school children. Journal of Abrurmal Psychology, 1932, 27, 243-264.

Pederson, D. M. Developmental trends in personal space. Journal of Psychology 1973, 83, $3-9$. 
Pederson, D. M., \& Shears, L. M. A review of personal space research in the framework of general systems theory. Psychological Bulletin, 1973, 80, 367-388.

Perkins-Karniski, M. A. The effect of increased knowledge of body systems and functions on attitudes toward the disabled. Rehabilitation Counseling Bulletin, 1978, 22, 16-20.

Peterfreund, E. Some critical comments on psychoanalytic conceptualizations of infancy. International .Journal of Psychoanalysis, 1978, 59, 427-441.

Piaget, J. The child's conception of the world. New York: Harcourt Brace, 1929.

Piaget, J. The origins of intelligence. New York: International Universities Press, 1952.

Popper, K. R. \& Eccles, J. C. The self and its brain. New York: Springer-Verlag, 1977

Porter, E., Argyle, M., \& Salter, V. What is signalled by proximity? Perceptual and Motor Skills, 1970, 30, 39-42.

Provence. S., \& Lipton, R. C. Infants in institutions. New York: International Universities Prcss, 1962.

Ralph, J. B., Thomas, A., Chess, S., \& Korn, S. J. The influence of nursery school on social interactions. American Journal of Orthopsychiatry, 1968, 38, 144-152.

Rapaport, D. The theory of ego autonomy: A generalization (1957). In M. M. Gill (Ed.), The collected papers of David Rapaport. New York: Basic Books, 1967. Pp. 722 - 744.

Reese, H. W., \& Lipsitt, L. W. Experimental child psychology. New York: Academic Press, 1970.

Reuter, J., \& Yunik, G. Social interaction in nursery schools. Developmental Psychology, $1973,9,319-325$.

Rheingold, H., \& Eckerman, C. O. Fear of the stranger: A critical examination. In H. W. Reese (Ed.), Advances in child development and behavior, (Vol. 8). New York: Academic Press, 1973. Pp. 185-222.

Ricciuti, H. Fear and the development of social attachments. In M. Lewis, \& L. A. Rosenblum (Eds.), The origin of fear. New York: Wiley, 1974. Pp. 73-106.

Roe, K. V. Infants' mother-stranger discrimination at 3 months as a predictor of cognitive development at 3 and 5 years. Developmental Psychology, 1978, 14, 191- 192.

Ross, H., \& Goldman, B. D. Infants' socialibility toward strangers. Child Development. $1977,48,638-642$.

Sanders, J. L. Relation of personal space to the human menstrual cycle. Journal of Psychology, 1978, 100, 275-278.

Scarr-Salapatek, S. Comments on "Heart rate: A sensitive tool for the study of emotional development in the infant." In L. Lipsitt (Ed.), Developmental psychology. Hillsdale, N. J.: Erlbaum, 1976. Pp. 32-34.

Schaffer, H. R., \& Emerson, P. E. The development of social attachment in infancy. Monographs of the Society for Research in Child Development, 1964, 29 (3, Serial No. 94).

Schaffer, H. R. The onset of fear of strangers and the incongruity hypothesis. Journal of Child Psychology and Psychiatry, 1966, 7, 95-106.

Schaffer, H. R. Cognitive structure and early social behavior. In H. R. Schaffer (Ed.), The origins of human social relations. New York: Academic Press, 1971.

Schaffer, H. R. Cognitive components of the infant's response to strangers. In M. Lewis \& L. A. Rosenblum (Eds.), The origins of fear. New York: Wiley, 1974. Pp. 11-24.

Schilder, P. The somato-psyche in psychiatry and social psychology. Journal of Abnormal Psychology, 1934, 29, 314-327.

Schneirla, T. C. An evolutionary and developmental theory of biphasic processes underlying approach and withdrawal. Nebraska Symposium on Motivation (Vol. 7). Lincoln, Neb. Univ. of Nebraska Press, 1959. Pp. 1-42.

Schneirla, T. C. Aspects of stimulation and organization in approach/withdrawal processes underlying vertebrate behavioral development. Advances in the Study of Behavior (Vol. 1). New York: Academic Press, 1965, Pp. 1-74. 
Shaffran, R. Modes of approach and the infants' reaction to the stranger. In T. Decarie (Ed.), The infant's reaction to strangers. New York: International Universities Press, 1974. Pp. 149-186.

Shea, J. D. Changes in interpersonal distances and categories of play behavior in the early weeks of preschool. Developmental Psychology, 1981, 17, 417-425.

Shirley, M. The first two years: A study of 25 babies. Institute of Child Welfare Monograph Series, No. III. Minneapolis: Univ. of Minneapolis Press, 1933.

Simpson, G. G. Principles of animal taxonomy. New York: Columbia Univ. Press, 1961.

Skarin, K. Cognitive and contextual determinants of stranger fear in 6- and 11-month-old infants. Child Development, 1971, 48, 537-544.

Smith, P. K. Social and situational determinants of fear in the playgroup. In M. Lewis \& L. A. Rosenblum (Eds.), The origins of fear. New York: Wiley, 1974. Pp. 107-129.

Snyder, M. On the influence of individuals on situations. In N. Kantor \& J. F. Kihlstrom (Eds.), Personality, cognition and social interaction. Hillsdale, N.J.: Erlbaum, 1981. Pp. 309-329.

Sommer, R. Studies in personal space. Sociometry, 1959, 22, 287-360.

Sommer, R. Personal space: The behavioral basis for design. Englewood Cliffs, N.J.: Prentice-Hall, 1969.

Sorce, J. F., \& Emde, R. N. Mother's presence is not enough: Effect of emotional availability on infant exploration. Developmental Psychology, 1981, 17, 737-745.

Spitz, R. A. Anxiety in infancy: A study of its manifestations in the first year of life. International Journal of Psychoanalysis, 1950, 31, 138-143.

Spitz, R. A. A genetic field theory of ego formation. New York: International Universities Press, 1959.

Spitz, R. A., \& Cobliner, N. The first year of life. New York: International Universities Press, 1965.

Sroufe, L. A. Wariness of strangers and the study of infant development. Child Development, 1977, 48, 731-746.

Sroufe, L. A., Waters, E., \& Matas, L. Contextual determinants of infant affective response. In M. Lewis \& L. A. Rosenblum (Eds.), The origins of fear. New York: Wiley, 1974. Pp. 49 72.

Stechler, G., \& Carpenter, G. A viewpoint on early affective development. In J. Hellmuth (Ed.), Exceptional infant, Vol. 1, The normal infant. Seattle: Special Child Publications, 1967. Pp. 163-189.

Stern, D. N. General issues in the study of fear. In M. Lewis \& L. A. Rosenblum (Eds.), The origins of fear. New York: Wiley, 1974. Pp. 258-262. (a)

Stern, D. N. Mother and infant at play: The dyadic interaction involving facial, vocal, and gaze behaviors. In M. Lewis \& L. A. Rosenblum (Eds.), The effect of the infant on its caregiver. New York: Wiley, 1974. Pp. 187-213. (b)

Stevens, A. G. Attachment behavior, separation anxiety, and stranger anxiety in polymatrically reared infants. In H. R. Schaffer (Ed.), The origins of human social relations. New York: Academic Press, 1971. Pp. 137-146.

Stone, L. J., \& Church, J. Childhood and adolescence. New York: Random House, 1973. 3rd ed.

Sundstrom, E., \& Altman, I. Interpersonal relationships and personal space: Research review and theoretical model. Human Ecology, 1976, 4, 47-67.

Szekely, L. Biological remarks on fears originating in early childhood. International Journal of Psychoanalysis, 1954, 35, 57-67.

Tennes, K. H., \& Lampl, E. E. Stranger and separation anxiety in infancy. Journal of Nervous and Mental Disorders, 1964, 139, 247-254.

Thompson, W. R., \& Grusec, J. E. Studies of early experience. In P. H. Mussen (Ed.), 
Carmichael's manual of child psychology (Vol. 1). New York: Wiley, 1970. 3rd ed.. pp. $565-654$.

Tizard, J., \& Tizard, B. The social development of two-year-old children in residential nurseries. In H. R. Schaffer (Ed.), The origins of human social relations. New York: Academic Press, 1971. Pp. 147-161.

Tolpin, M. On the beginnings of a cohesive self: An application of the concept of transmuting internalization to the study of the transitional object and signal anxiety. Psychoanalytic Study of the Child, 1971, 26, 316-352.

Trause, M. A. Stranger responses: Effects of familiarity, stranger's approach, and sex of infant. Child Development, 1977, 48, 1657-1661.

Trevarthen, C. Communication and cooperation in early infancy: A description of primary intersubjectivity. In M. Bullowa (Ed.), Before speech. New York: Cambridge Univ. Press, 1979. Pp. $321-347$

Turnure, C. Response to voice of mother and stranger by babies in the first year. Developmental Psychology, 1971, 4, 182-190.

Volkert, E. H. (Ed.) Social behavior and personality: Contributions of W.I. Thomas to theory and social research. New York: Social Science Research Council, 1951.

von Cranach, M. Ethology and human behavior. In J. Isreal \& H. Tajfel (Eds.), The context of social psychology. A critical assessment. New York: Academic Press, 1972. Pp. $370-392$.

Waters, E., Matas, L., \& Sroufe, L. A. Infants' reactions to an approaching stranger: Description, validation, and functional significance. Child Development, 1975, 46, $348-356$.

Watson, J. S. Smiling, cooing and "the game." Merrill-Palmer Quarterly, 1972, 15, $323-340$.

Watson, O. M. Proxemic behavior: A cross cultural study. Paris: Mouton, 1970.

Weinraub, M., \& Putney, E. The effects of height on infants' sound responses to unfamiliar persons. Child Development, 1978, 49, 598-603.

Weinstein, E. A. Disorders of the body schema in organic mental syndromes. In P. J. Vinken \& G. W. Bruyn (Eds.), Handbook of clinical neurology, (Vol. 4). New York: Wiley. Pp. 241-247.

Weinstein, L. Social schemata of emotionally disturbed boys. Journal of Abnormal Psychology, 1965, 70, 457-461.

Weiss, E. The structure and dynamics of the human mind. New York: Grune \& Stratton, 1960.

Werner, H. Comparative psychology of mental development. New York: Harper, 1940.

White, B. Human infants: Experience and psychological development. Englewood Cliffs, N.J.: Prentice-Hall, 1971.

White, B. The first three years of life. Englewood Cliffs, N.J.: Prentice-Hall, 1975.

White. R. W. Motivation reconsidered: The concept of competence. Psychological Review. $1959,66,297-333$.

Whiteside, M. F., Busch, F., \& Horner, T. M. From egocentric to cooperative play in young children. Journal of the American Academy of Child Psychiatry, 1976, 15, 294-313.

Wohlwill, J. Cognitive development in children. In J. Ragan \& O. G. Brim (Eds.), Constancy and change in human development. Cambridge, Mass.: Harvard Univ. Press, $1980,359-445$.

Wolff, P. H. Observations on the early development of smiling. In B. M. Foss (Ed.), Determinants of infant behavior (Vol. 2). New York: Wiley, 1963.

Wynne, L., \& Singer, M. Thought disorder and family relations of schizophrenics: II. A clarification of forms of thinking. Archives of General Psychiarry, 1963, 9, 199-206.

Young, G., \& Lewis, M. Effects of familiarity and maternal attention on infant peer relations. Merrill-Palmer Quarterly, 1978, 25, 105-119.

Receivfo: May 1, 1981: ReVised: July 7, 1982. 